\title{
Ou-Testamentiese perspektiewe op lyding
}

\author{
J.L. Helberg \\ Departement Ou \& Nuwe Testamtent \\ Potchefstroomse Universiteit vir $\mathrm{CHO}$ \\ POTCHEFSTROOM
}

\begin{abstract}
In this article attention is directed to perspectives on suffering in the Old Testament and briefly to the implications for the praxis of ministry to those who suffer. The following issues are discussed: the relation between suffering and sin; suffering in the relation to God, the neighbour, oneself and the earth. The Word of God, prayer and the communion of the saints play an important role in this ministry and the implied self-ministry of the sufferer. Attention is directed to aspects like the following: the relevance of Psalms in the Old Testament especially the laments in the Psalms - and in contemporary worship; sin. God's sovereignty and the mystery of his action; the place of enemies; cause- and goal-directed suffering; setfencouragement; communion and the inclination to serve.
\end{abstract}

\section{Inleiding}

Lyding is ' $n$ decl van ons lewe en kom voor rondom geboorte, suiglingsjare, kinderjare en pubcrteit; rondom die liefdeslewe, huwelik en gesin; in teleurstelling en mislukkings; in teenslae in die finansiële lewe en die natuur, in siekte, dood, eensaamheid en ouderdom. Lyding maak ook deel uit van ons huidige maatskaplike en staatkundige landsomstandighede met sy stryd en selfs gewelddadigheid. In hierdie artikel word ingegaan op Ou-Testamentiese perspektiewe op lyding en word kortliks implikasies aangedui vir die vormgewing (praxis) van lydensbediening. Daar sal ingegaan word op die verhouding tussen lyding en sonde en op lyding in die verhouding tot God, die naaste, 'n mens self en die aarde. Hierdie benadering word gevolg op grond van die vier uitgesproke of onuitgesproke vrae aan die begin van die mens se geskiedenis volgens Genesis. Hierdie vrae kenmerk die verhoudinge waarin die mens staan en waarin sy lyding veral gestalte kry. Ná die mens se sonde in die tuin van Eden kom die vraag aan hom: "Waar is jy?". In die geskiedenis spoedig daarna kom die vraag aan Kain: "Waar is jou broer?". By die bou van Babel, waar die mensdom in hulle beplanning vir eenheid nie met God reken nie, kom die onuitgesproke vraag: "Waar is jou God?". In die roeping van Abraham en die belofte van die land wat aan hom 
gemaak word, kom die mens se heimwee na sy woonplek op aarde ter sprake in aansluiting by sy verdrywing uit die tuin van Eden.

\section{Lyding en sonde}

Volgens Genesis 1-3 het die lyding in die wêreld gekom deur die mens se ongehoorsaamheid aan God, gepaard met ondankbaarheid en ongeloof of ' $n$ gebrek aan vertroue in God. Die mens was ongehoorsaam en het geëet van die boom waarvan God hom verbied het om te eet. Hy was ondankbaar en het gemeen dat hy op meer aanspraak het as wat God hom gegee het. Hy het nie vertroue in God gehad nie maar het gemeen dat hy eerder voordeel sou hê uit die verbode optrede ("Julle sal gewis nie sterf nie, maar God weet dat julle oë sal oopgaan ... en dan sal julle soos God wees deurdat julle alles kan ken" - Gen. 3:4-5). Weens die sonde sal die vrou smart hê in verband met swangerskap en die man in die uitoefening van sy werk (Gen. 3:16-19). Die geskiedenis wat hierop volg, is vol sonde en smart, soos die optrede van Kain en die mense voor en na die sondvloed getuig (Gen. $4 ; 6: 11-13$ ).

Dit is ook die geval dwarsdeur die Ou Testament. Die hele situasie rondom die wetgewing by Sinai en die woestynreis word gekenmerk deur sonde en die ellende wat daarop volg (Eks. 32-33; Num. 11-14; 16; 25; ens.). Dieselfde geld by die intog in Kanaän (vgl. die optrede van Akan - Jos. 7). Die rigtertyd word gekenmerk deur 'n siklus van ontrou aan die Here, straf, die roep om hulp en die verwek van 'n leier deur die Here om sy volk te verlos. Die koningstyd word gekenmerk deur die volgende refrein wat die konings sowel as die volk tipeer: "Hy het gedoen wat verkeerd was in die oë van die Here" (2 Kon. 13:10; 15:9, 18; ens.). Salomo se gebed by die inwyding van die tempel spreek van sonde, straf en vergifnis (1 Kon. 8:22-51). Die psalmdigters bely hulle sonde as oorsaak van hulle smart (Ps. 38; 51; 130). In Psalm 90:5-11 word die mens se verganklikheid in verband gebring met sy sonde. Ook die wysheidsleraars bring rampe en sonde met mekaar in verband (Spr. 12:21; 28:18).

Veral die profete lê 'n verband tussen Israel se ellende en hulle sonde en verkondig God se vernietigende straf daaroor (Am. 1-2; Jes. 6:11-13; Jer. 1:10, 16: Eseg. 2:3-5). Hulle sien die geskiedenis afstuur op die verskriklike dag van die Here, die dag van oordeel (Am. 5:18-20; Joël 1:15-16; 2:12 e.v.). Selfs die boek Daniël wat oor die verbondsvolk se geloofsvervolging handel, bevat ' $n$ hartroerende belydenis van sonde en ' $n$ smeekbede om vergifinis (Dan. 9). In die boek Klaagliedere word Israel se sonde bely op 'n aangrypende manier as oorsaak van die val van Jerusalem en die wegvoer van die volk in ballingskap. Jeremia verbind die nuwe verbond met Israel se oortreding en met God se vergewing (Jer. 31:28-34). In die boek Hosea word God se straf, maar ook sy grondelose liefde vir sy verbondsvolk verkondig (vgl. byvoorbeeld Hos. 2). 


\section{Lyding en die verhouding tot God}

Die lydende persoon se verhouding tot God is van primêre belang, soos die begin van die Skrif duidelik aantoon. Die mens het homself as 'n opstandige wese teenoor God betoon; daarom is hy uit die tuin van Eden gedryf (Gen. 4:24) en het hy ' $n$ vreemdeling by God geword. Tog het hy van God klere gekry (Gen. 3:20), wat 'n teken is van God se sorg vir hom. Ook na die sondvloed as straf oor die sonde van die mensdom in die tyd van Noag beloof God sy sorg aan die mensdom - ondanks die feit dat die mens nog net so korrup soos vroeër was (Gen. $6: 5-7 ; 8: 21-22$ ). Die mens se lewe kan en moet dus deur dankbaarheid gedra word - 'n gedagte wat ook in baie dankpsalms vergestalt word (Ps. 9; 18; 23; 30; $32 ; 107$, ens.).

Abraham se geskiedenis leer dat die mens, vir wie God genadig is en wat in geloof op God se roeping reageer, tog weer in ' $n$ versoende verhouding met God te staan kom. Hierdie verhouding word selfs in 'n verbond vasgelê (Gen. 12; 15; 17). Die mens word as verbondskind volgens die Ou Testament so onder God se beskerming geneem, dat hy die tern vreemdeling in 'n positiewe sin van homself kan gebruik as iemand wat net op God se beskennende teenwoordigheid aangewese is en dit ook inderdaad ondervind (Ps. 39:13; 119:19; vgl. die 1933/53 en die 1983-Afrikaanse vertalings). Om in hierdie sin ' $n$ vreemdeling by God te wees is dus om by God geborge te wees.

Hierdie vreemdelingskap stimuleer die gelowige in die Ou Testament egter nie tot wêreldontvlugting nie. Die gelowige word voluit in hierdie wêreld gestel. Reeds hier kan die reddende optrede van God vir die lydendes duidelik gesien word (vgl. byvoorbeeld die lofsang van Hanna in 1 Samuel 2 oor die verwagting van die lydende die wyse waarop God die situasie vir hom of haar ten goede gaan verander).

Aangesien lyding primêr met die verhouding tot God te maak het, is gebed 'n besonder belangrike saak in die versterking en bemoediging in lyding (vgl. ook Schaller, 1990:3, 5, 6). Die psalmdigters gee dikwels uiting aan hulle gebedsworsteling met God oor die verhouding met Hom. Hierdie worsteling spruit dikwels juis uit die gevoel by die gelowige dat God Hom afsydig hou en selfs nie op die gebedsworsteling reageer nie (Ps. 43:1; 69:2-4; 88:6-9; 130:1; Klaagl. 3:1-18; Jona 2:3-7). Die aanvegting wat die mens verskeur, is in die Psalms nie ' $n$ teoretiese nie-bestaan van God nie, maar 'n praktiese onwerksaamheid van God (vgl. Fuchs, 1982:330; Perlitt, 1971:367, 377): van hierdie aspek is Psalm 42-43 'n duidelike voorbeeld (vgl. vir die eenheid van die twee psalms Helberg, 1993: 110-112; Ridderbos, 1958:9). Hierdie psalms bied ook 'n voorbeeld van hoe die lydende sy saak by God bepleit. Die pleitrede gaan in kem om God se teenwoordigheid en sy verbondstrou. God word herinner aan sy genadeverhouding wat in 'n verbond vasgelê is en Hy word gevra om dit te gedenk (רז, 42:5). 
Die lydende doen 'n beroep op God se liefde en trou ( $707,42: 9$; vgl. Sakenfeld, 1978:230, 231) en gee uitdrukking aan sy liefdesverhouding met God deur die intieme verbondsaanspraak "my God" (אלוֹ hierdie aspekte Helberg, 1993). Verder gee hy uiting aan sy heimwee na God as die lewende God, die God wat oor alles en almal heerskappy uitoefen (vgl. Kreuzer, 1983:275). God is vir hom tegelykertyd die "God van my lewe", die God wat lewe gee en onderhou en selfs uitkoms kan bewerk uit 'n ondergangsituasie soos dié waarin die lyer hom bevind. Dit alles getuig daarvan dat die lydende uit vertroue op God moet lewe.

Psalm 51 gee uiting aan die lyer se diepe skuldbesef. Hy kom tot volle innerlike bevryding deur niemand anders vir sy ellende te verwyt nie as net homself en sy sonde teenoor God. Hierdie innerlike bevryding gee hom die vrymoedigheid om te bid om God se genade, troue liefde en barmhartigheid (Ps. 51:3). Hy besef dat God verootmoediging wil hê. God sal 'n hart vol ootmoed en berou nie gering ag nie (Ps. 51:19). God kan selfs 'n mens se hart verander. Hy kan in sy genade 'n berouvolle sondaar se sondes vergewe. Hy kan ook vir hom 'n rein hart skep deur sy Heilige Gees (Ps. 51:11-14). Daarmee open Hy ook vir 'n mens die weg van versoening en vrede met die naaste.

Nie alle worsteling in die Psalms gaan oor die lydende se sonde nie, in elk geval nie direk nie. In die digter se worsteling in Psalm 42-43 kom sonde nie ter sprake nie, en in die omringende Psalms (41 en 44) is daar eerder onskuldbetuigings. Ook in die lofsang van Hanna kom eie sonde nie ter sprake nie. Dieselfde geld vir die boek Job: die oorsaak van die lyding is God se geding met die Satan. Hierdie boek laat sien dat dit in die godsdiens gaan om God te dien ter wille van Homself, nie ter wille van die voordeel daarvan nie (Kroeze, 1961:30). Anders as die lesers van die boek Job is Job self nie bewus van die geding tussen God en die Satan nie en daarom van die oorsaak en doel van sy spesifieke lyding nie. Hy moet hom onvoorwaardelik en gewillig aan God se weg met sy lewe onderwerp. Dit gaan om die erkenning van God se vrymagtige seggenskap en heerskappy in 'n mens se lewe - 'n aspek wat vooropstaan in ware godsdiens. God betoon Hom egter tegelykertyd in die boek Job as die God wat aan Job verskyn, die God wat teenwoordig is by die gelowige. Dit is in die erkenning van God se vrymag en tegelykertyd sy genadige teenwoordigheid dat Job innerlike rus en vrede vind (Job 42:1-6). Eers daarna ontvang hy weer voorspoed van God. Voorspoed kom nie outomaties nie, maar as 'n genadegawe. Voorspoed val ook nie alle mense te beurt nie, soos die talle psalms uit die hart van lydendes getuig.

Met bostaande uitgangspunt word verskillende benaderings afgesny: 'n utiliteitsbenadering waarvolgens die bidder alles kry wat hy graag wil hê - insluitende 'n einde aan sy lyding - as hy maar net gelowig genoeg bid, 'n verdienstelikheidsbenadering waarvolgens ' $n$ mens se voorspoed ' $n$ teken is van ' $n$ opregte lewe en lyding ' $n$ teken van ' $n$ verkeerde lewe; ' $n$ irrasionele benadering waarvolgens ' $n$ 
mens die slagoffer is van willekeurige, doellose of fatalistiese gebeure en magte. In Job word wel die weg geopen vir 'n benadering wat die misterie van die vrymagtige en goeie God se weg met 'n mens se lewe erken en vrede daarin vind (vgl. ook Oosterhoff, 1971:32-34, 44: God het baie redes vir sy optrede maar gee nie daarvan rekenskap nie). Anders as by ' $n$ mitologiese benadering is die fokus nie gerig op geheimsinnige magte nie; en anders as by 'n homosentriese benadering is die fokus nie gerig op die belange van die bidder of op die slegtheid van die vyande nie. In Job vind ons 'n teosentriese benadering. Die klem val op die verhouding met Hom en die buig voor sy wil.

Gelowiges word dus voor die taak gestel om veral in ons huidige situasie van geweldpleging en bedreiging die regte perspektief te kry op twee uiteenliggende pole. Hierdie perspektief raak enersyds die eis om ordelike landsbestuur wat regverdigheid, straf en vergelding impliseer, en andersyds die Skrif se eis oor hoe 'n gelowige lyding moet hanteer.

\section{Lyding en die verhouding tot die naaste}

Baie van die mens se lyding kom voor in onderlinge verhoudinge, en dié verhouding trek saam in die huweliks-, gesins- en familieverhoudings. Reeds die eerste hoofstukke van die Skrif teken die skeefgetrokke verhouding tussen man en vrou ("Die vrou wat $\mathrm{U}$ my gegee het ... het vir my van die boom se vrugte gegee", Gen. 3:12) en van broers onderling (Kain vermoor vir Abel, Gen. 4). 'n Groot deel van die psalmdigters se lyding het te doen met hulle verhouding tot die medemens (bv. Ps. 35:11-16; 38:11-15;41;6-11;42:4, 11). Die lyding trek veral saam in die vyandigheid wat hulle van hulle vyande ondervind, en onder hierdie vyande tel ook mense wat as vriende deurgaan (Ps. 31; 38, 41). Lyding raak vyandigheid in alledaagse verhoudinge, vyandigheid van hulle wat ' $n$ mens in werklikheid behoort by te staan en saam met jou in een juk behoort te trek. Die vyande maak veral daarop aanspraak dat die lydende deur God verwerp is (Ps. $22: 9 ; 42: 4 ; 71: 10-11$ ).

In die Psalms speel die vyande so ' $n$ groot rol dat dit vir sommige hedendaagse lesers ' $n$ verleentheid skep: dit geld veral die vergeldingsgedagte wat so sterk daarin na vore kom (Ps. 3:8; 5:11;7:7; 9:20-21; 17:13-14; ens.). Andersyds is dit ' $n$ vraag of die stryd met die vyande nie 'n te groot rol in ons praktyk speel nie: daarvoor word wel 'n direkte of indirekte beroep op die Psalms en die res van die Ou Testament gedoen. Vyandskap kan maklik 'n ereplek gegee word in die naam van antitese.

Daar is al dik boeke geskryf oor die vyande in die Psalms en die vyande is onder meer gesien as valse aanklaers, waarsêers en demoniese magte, en die koning se vyande (Miller, 1986:50, 51), en nog is die probleem nie opgelos nie. Na my oortuiging is die feit dat die vyande dikwels in die Psalms genoem word, veral toe te 
skryf aan die aksent wat Israel daarop gelê het binne hulle konkrete situasie. In hulle soeke na 'n rede vir lyding, het Israel se bure die toevlug geneem tot mitologiese oorsake. Hulle het lyding toegeskryf aan die misterieuse optrede van onsigbare magte soos geeste, toordery, ensovoorts. Die Bybelse godsdiens daarenteen, lê die klem op historiese gebeurtenisse. Israel het die lewe nie gemitologiseer nie, maar gehistoriseer. Selfs hulle landboufeeste is 'gehistoriseer'. Die klem is op die geskiedkundige gebeurtenisse gelê, nie op die natuurprosesse of die opbrengste self nie (Vriezen, 1966:280-282). Hierdie historiese benadering van sake het vir die lyer 'n geweldige bevryding gebring; hy is bevry van die verslawing van die geloof in irrasionele magte as bepalers van sy lyding en lot. Daar moet wel rekening gehou word met die feit dat die indiwiduele klaagliedere in die $\mathrm{Ou}$ Testament in baie opsigte sterk stereotiep is. Die historiese vyand word soms in skerp kleure geskilder, gewoonlik in sterk taal en negatiewe beelde, ontleen aan die diere, oorlog, jag ensovoorts (Miller, 1986:62,63). Die klem val dus nie bloot op die vyand as historiese enkeling nie, maar sterker op die konkrete verskynsel van vyandskap wat die lyer op grond van mense se optrede ondervind. Reventlow (1986: 171) sê dan ook tereg dat dit nie gaan om die vyand as sodanig nie, maar om die verhouding tot God wat in gedrang is (vgl. ook Limbeck, 1977: 5, 6 oor die feit dat elke klaaglied drie faktore omvat: God, die bidder en die vyande).

Die gelowige het die taak om ook die vyand tot bekering op te roep - in die gesindheid om aan ander te doen soos jy graag aan jouself gedoen wil hê. Hierdie benaderingswyse is baie belangrik in die bediening aan die lydendes sodat hulle in hulle verhouding tot hulle naaste tot ware bevryding te kom. So kan hulle selfs in hulle verhouding tot hulle vyande doelgerigtheid en sinvolheid ervaar - iets wat ' $n$ besondere stukrag aan ' $n$ lyer in sy ellendige situasie gee.

Die Ou Testament bied ook ' $n$ nog wyere visie op lyding en die sin daarvan. In die Ou Testament word as taak gestel om vrywillig lyding op te neem ter wille van ander, selfs lyding wat deur die ander se vyandskap bewerk word (vgl. byvoorbeeld die liedere oor die lydende dienaar, Jes. 50; 53). Hierdie belangrike en bevrydende aspek van lyding is in ons teologie en prediking verwaarloos. ( $\mathrm{Vgl}$. hierteenoor die pleidooi van Brueggemann (1992:22-44) vir die "embrace of pain" in die Ou Testament.) Dié betrokke Skrifgedeeltes is ook te maklik in hulle geheel betrek slegs op die toekomstige Verlosser, Jesus Christus. In werklikheid het hulle ook op die volk en op Israel betrekking, al is dit nie op presies dieselfde manier nie. (Hulle vorm 'n onderdeel van die dienaargedeeltes, hfst. 41-55, waarin daar oor Israel se dienaarskap gehandel word; vgl. 42:8, 9 ens.)

Hierdie soort verkondiging vind nie veel aanklank by ' $n$ mens se natuurlike ingesteldheid nie. 'n Mens kom eerder in verset daarteen, beskou dit as swakheid en beroep jou by God op jou regte teenoor ander mense. Dit het by die verbondsvolk dan ook ' $n$ heel besondere situasie gekos om hulle enigsins vatbaar te maak 
vir hierdie verkondiging, naamlik die situasie van ballingskap. (Die hoofstukke in Jesaja wat oor die dienaar handel, slaan op hierdie situasie, ongeag daarvan of hulle in die tyd van Jesaja geskryf is of nie.) Israel was in 'n situasie van swaar lyding, en wel een wat hulle as die gevolg van hulle eie sonde erken en voor God bely het. Binne hierdie troostelose situasie waarin hulle hulle lyding slegs as 'n gevolg van hulle sonde kon sien en bely (Klaagl.), het hierdie verkondiging vir hulle 'n nuwe perspektief gebring. Hulle het dit ontvang waarna 'n lydende so innig smag: doelgerigtheid vir, singewing aan die lyding. Selfs toe en daarna het hierdie verkondiging van Jesaja egter nie veel navolging of weerklank gevind nie. In ons landsomstandighede van stryd en gewelddadigheid met al die lyding daaraan verbonde, word bedienaars se neus as ' $t$ ware weer op hierdie belangrike aspek gedruk. Daarmee kom ook Jesus Christus se eis om selfs vyande lief te hê duidelik aan die orde (Matt. 5:43-48).

Ook Daniël se drie vriende vertoon so 'n selfverloënende en bevrydende geloof in hulle belydenis: "God het die mag om te red ... en Hy sal ons ook red ... Selfs as Hy dit nie doen nie, moet u weet dat ons u god nie sal dien nie" (Dan. 3:17, 18; vgl. Preuss, 1992:304). Soos Israel in die ballingskapstyd leef ook ons nog nie in die tyd van volledige redding nie, maar in die tyd van die belofte, van die reeds en tog nog nie (vgl. Rom. 8:18-25; vgl. ook Floor, 1981:79; Fuchs, 1982:333). Op sy pad in hierdie intense stryd om tot so 'n belydenis te kom, het die gelowige begeleiding nodig.

\section{Lyding en die verhouding tot 'n mens self}

Na hulle sonde in die tuin van Eden ontdek Adam en Eva dat hulle naak is en kruip weg. Hulle is verleë met hulleself. God praat met elkeen indiwidueel en gee hulle afsonderlike strawwe, hoewel hulle daardeur ook in hulle verhouding tot mekaar geraak word. Hierdie sterk indiwidueel-persoonlike inslag is ook duidelik in die Psalms: die gelowige bevind hom sterk indiwidueel voor God en bestraf homself selfs. Die mens betoon hom in die tuin van Eden as iemand wat nie die oorsaak van sy ellende in die oe kan kyk of wil kyk nie. As hy daaroor tot verantwoording geroep word, plaas hy die skuld op sy naaste en op God ("Die vrou wat $U$ my gegee het ... het vir my van die boom se vrugte gegee", "Die slang het my bedrieg" - Gen. 3:12-13). 'n Mens moet homself eers as sondaar ontdek voordat sy gesindheid oopgaan om tot die oorsaak, sin en doel van lyding te kan deurdring. Eers wanneer hy tot die kernoorsaak van sy vreemdelingskap op aarde deurdring, kan hy bewus raak van waarom hy selfs te midde van die teenwoordigheid van sy naaste en God tog nog eensaam en verlate kan voel. Dan is ' $n$ mens se heimwee nie maar ' $n$ vae verlange nie (Lamparter, 1961:220), nie ' $n$ verlange na 'n onbekende God nie, maar na die lewende God, die alleen ware God, wat sy Naam bekend gemaak het (Ps. 42-43; vgl. ook Reventlow, 1986: 174). Eers dan kan hy homself in die oe kyk en die verleentheid met homself te bowe kom. 
Die werklikheid van God in die gelowige se lewe maak dat hy bokant homself en sy lyding kan uitstyg en teenoor homself, sy lyding en selfs sy vertwyfeling kan gaan staan en sy lewe deur hoop laat dra. Hierdie hoop word veral in Psalm 42 tot 43 gesien, waar, soos reeds aangetoon is, die klem so sterk op hierdie hoop en op die (verbonds)verhouding met God lê dat sondebelydenis nie eens (uitdruklik) ter sprake kom nie. Die digter raak in die diepste vertwyfeling, maar hy spoor homself telkens aan met ' $n$ beroep om onwrikbaar aan die hoop vas te hou. Uit die dieptes breek telkens die refrein van selfaansporing deur: "Waarom is ek so in vertwyfeling en waarom kerm ek so? Vertrou op God! Ja, ek sal weer vir Hom 'n loflied sing. Hy is my helper en my God!" (Ps. 42:6, 12; 43:5). Die grond vir hierdie selfaansporing tot hoop is nie die digter se eie geloof of dit wat hyself uitgeredeneer het nie, maar God self. Dit geld dan ook wel God wat weens sy verbond aangedui kan word as " $m y$ God". Met hierdie term spreek die psalmdigters deur hulle vrae en angste heen hulle vertroue in God uit (Eissfeldt, 1945/ 1948:8-10; 12-16; Schmidt, 1971:162; Ringgren, 1973:299, 300). Met die uitroep my God gee hulle ruimte vir die vrymag van God in die manier van sy optrede, al vra dit worsteling.

Die gedagte dat God met sy volk op pad is en dat dinge vir hulle as groep en as enkelinge na 'n doel toe beweeg, is ' $n$ bron van krag vir die digter van Psalın 42 en 43 in sy ellendige situasie.

\section{Lyding en die verhouding met die aarde}

Deur die mens se sonde is die aarde vervloek en die verhouding tussen hulle skeefgetrek. Op grond van die sonde van die skeefgetrokke verhouding word die mens se bestaan op aarde deur swaarkry gekenmerk (Gen. 3). Verder is hy deur God uit die tuin van Eden gedryf en het hy ' $n$ vreemdeling geword in sy verhouding tot God en die aarde (Gen. 4:24). God roep uiteindelik vir Abraham en beloof om uit hom ' $n$ verbondsvolk te verwek wat in ' $n$ bepaalde land sal woon (Gen. $12 ; 15 ; 17)$. Met hierdie belofte word 'n herstelde verhouding van die mensdom tot God en die aarde gesimboliseer (Gen. 12:1-3). Die land is die nuwe tuin van Eden waarin Israel rus en vrede kan hê en die vrug van die aarde kan geniet. Israel verteenwoordig die mensdom, en die land die aarde (Wright, 1983:100, 139). God is die Skepper van alle dinge en alles behoort aan Hom.

Israel se bure het 'n natuurgodsdiens beoefen. Vrugbaarheid, voorspoed en teenspoed in die natuur is aan hulle gode toegeskryf. Die gode was prakties egter natuurkragte en daarom is probeer om hulle ten goede te manipuleer deur middel van rites. Elia wys dat hierdie aanspraak ongegrond is en dat God die enigste ware God is, die Skepper en Onderhouer van alles. Dit is Hy wat reën gee of weerhou (1 Kon. 18). Dit is tot Hom wat ' $n$ mens in lyding die toevlug moet neem. Die middel daavoor is nie manipulasie nie, maar gebed en oorgawe aan sy wil (1 Kon. 19). In Salomo se gebed word enersyds 'n sterk verband gelê tussen 
die volk se sonde, reën, droogte, hongersnood, landbouplae en aanvalle deur vyande en andersyds op gebed, vergewing en 'n gehoorsame lewe aan God. Jesaja 40 tot 66 benadruk sowel God se hoedanigheid as Skepper sy hoedanigheid as Verlosser (vgl. byvoorbeeld Jes. 40-41). Die vastigheid van God se skeppingswerk word deur Jeremia voorgehou as 'n waarborg van die vastigheid van God se verbond met Israel (Jer. 31:35-37). Esegiël benadruk weer dat God alles ter wille van Homself doen (Eseg. 36:22-24).

Uit die voorafgaande blyk dat volgens die Ou Testament droogtes, rampe, ensovoorts nie toevallig oor ' $\mathrm{n}$ mens kom of die blote gevolg van natuurkragte is nie, maar dat dit onder God se bestier staan. (Vgl. Vriezen, 1966:457; Von Rad, 1962:152 oor die feit dat die Ou Testament nie 'n neutrale natuur ken nie.) Daar is 'n noue verband tussen natuurrampe en die mens se sonde. Die volgende gevolge van die mens se basiese sonde, naamlik die sug na outonomie teenoor God, word deur Wright (1983:71-73) uitgewys: eerstens word land en hulpbronne die grootste rede vir stryd en oorlog; tweedens word werk enersyds 'n blote noodsaaklikheid in die bestaanstryd, en andersyds 'n blote kommoditeit vir koop en verkoop, ongeag die menslike werker; derdens word ekonomiese groei 'n patologiese obsessie en verdwyn die sin vir 'n transendente verantwoordelikheid vir ander mense. Daarmee is boosheid en ellende met die ekonomiese lewe verweef. In die lydensbediening moet ook die verantwoordelikheid van die mens in hierdie opsigte aan die orde kom.

\section{Ou-Testamentiese perspektiewe vir die vormgewing van lydens- bediening}

Die bediening van lydendes hou nie net in dat hulle met die Skrif bedien word nie, maar impliseer ook om hulle by die Bybel self te bring sodat hulle self dit gebruik as bron van krag (Ps. 1:2; 19:8-15; 119:33-40; 105-107). Al moet pastorale bediening aan lydendes onderrigtend wees, moet dit tog duidelik van onderrig of kategese as sodanig onderskei word en moet dit veral nie lank en swaarwigtig wees nie, maar kort en eenvoudig.

Uit die voorafgaande bespreking in hierdie artikel blyk dat daar 'n verband is tussen sonde en lyding, maar nie altyd op so ' $n$ wyse dat bepaalde lyding aan 'n bepaalde sonde in ' $n$ mens se lewe toegeskryf kan word nie. Wel moet die lydende persoon se verhouding met God, die naaste en die aarde betrek word, met inbegrip van sy verantwoordelikheid in al hierdie verhoudinge. Vervolgens word bediening bekyk veral in die lig van die klaagsange in die Ou Testament, asook in verband met die gemeenskap van die gelowiges. 


\subsection{Die bediening in verband met klaging}

\section{- Die aard van die klaging}

Die klaagsange wat veral in die Psalms voorkom, bied 'n skat van materiaal waarin die lydende saam met die digter sy hart voor God kan oopmaak. Die lydende hoef dus nie net voorligting oor sy lyding te ontvang nie, maar kan belewend sy saak oor sy swaarkry met God uitworstel. Die Psalmdigter is ook nie altyd beskeie in sy klaging nie. Soms beskuldig hy God selfs daarvan dat Hy hom veronreg (Ps. 43; 73; vgl. ook Job 23 en 24; die klaagliedere in die Psalmbundel hoef egter nie gesien te word as 'n verset teen die status quo in die samelewing nie, kontra Brueggemann, 1992:27-30). Volgens sommige geleerdes is daar ' $n$ kategorie psalms wat nie net klaging bevat nie, maar ' $n$ element van aanklag teen God (Westermann, 1977:159, 164; Broyles, 1989:40, 221; Fuchs, 1982:307). Gerstenberger (1980:60-63; 234-147) daarenteen, sien ook die element van aanklag tereg as deel van klaging; in alle indiwiduele klaag- of dankliedere word daar in ' $n$ mindere of meerdere mate vertroue uitgedruk (Keel, 1969:221). Die klaagsange verskil van dié van die heidense bure daarin dat dit nie bloot 'n subjektiewe gevoelsuiting van smart is nie, maar gebede. Ondanks die vryheid en selfs gewaagdheid van klaging, staan die gelowige tog onder gebedsdissipline en uiteindelik onder Goddelike korrektief. Hierdie feit is vir die bediening aan ' $n$ lydende van grondliggende betekenis.

Dit is in elk geval uit die klaagliedere duidelik dat die lydende, selfs die opstandige mens, nie dadelik van buite deur bediening tot swye gebring hoef te word nie. Hy kan sy saak enduit met God uitspook en tot 'n deurleefde antwoord op sy lyding kom. Sodoende kan hy innerlike rus en vrede bereik deurdat hy saam met die digter tot innerlike selfkorreksie kom. In die klaagliedere in die Ou Testament is daar dan ook ' $n$ beweging na lof toe (Miller, 1986:66; Beyerlin, 1967: 209). Die doel van ' $n$ mens se lewe is om God te eer en te prys (Miller, 1986:65$70,74,75)$.

\section{- Die plek van die klaging}

Westermann (1990:84-87) pleit vir 'n volwaardige plek vir die klaaglied in die $\mathrm{Ou}$ Testament. Hy sê dat die klaaglied ten onregte vir die meeste verklaarders 'n negatiewe betekenis het. In die moderne psigologie is die heilsame betekenis van die klaging lankal reeds erken. Verder sê hy dat die vraag 'Waarom kon God dit toelaat?' 'n belangrike plek het. Waar hierdie vraag nie meer gewaag kan word nie en uit die gebed uitgesluit is, word die verskriklike en onbegryplike kant van die werklikheid in die verhouding met God uitgeskakel. Dit lei daartoe dat mense weens die vreesaanjaende katastrofes in die privaat en openbare lewe God afsê en redeneer: 'Tot ' $n$ God wat so iets toelaat, kan ek nie meer bid nie' (vgl. Ps. 73). Daarom betreur Westermann (1990:192) dit dat die klaging in die Christelike gebed geen plek meer het nie (vgl. ook Fuchs, 1982:13; ook lof het tans 'n 
geringe plek, Ridderbos, 1970:15). Fuchs (1982:33, 34, 342-344) gaan weer te ver met sy kategoriese skeiding tussen 'suiwer klaagsange' en dié soos in die boek Klaagliedere. Die regverdiging van God deur die mens in Klaagliedere, is volgens Fuchs uiteindelik die dood van die klaging as gebed. Die teodiseeantwoord is gereed om die sonde te sien as die oorsaak van die betrokke lyding (vgl. ook Ballentine, 1989:611); al wat oorbly, is om te treur oor die sonde en jou te bekeer, om nie-meer-skuldig te wees. Fuchs het wel daarin gelyk dat die klaging oor sonde as die oorsaak van Israel se ellende in die ballingskap sentraal is in Klaagliedere, en so ook die bekering met die oog op die verandering van die toestand. Tog word klaging in die sin van Anklage nie daarmee uitgesluit nie (vgl. byvoorbeeld Klaagl. 2:20).

\section{- Die raamwerk van die klaging}

In die lig van bogenoemde is dit belangrik om daarop te wys dat die klaging in die Ou Testament sy plek binne ' $n$ groter raamwerk het. Hierdie soort psalms is deel van ' $n$ bundel waarvan die onderafdelings (Ps. 1-41; 42-72; 73-89; 90-106; 107 150) en die bundel as geheel, met lof aan God eindig. Met sy uitroep: "My God, my God, waarom het U my verlaat?", het Christus self die waarom-vraag gestel. Hy het die vraag egter ook in sy diepste wese en, vir ons, verbondsmatig beantwoord. Hy vervul die nuwe verbond deur dit met sy bloed, sy sterwe, te beseël (Matt. 26:28). Hy is deur God verlaat sodat ons met God versoen kan wees en sodat dié wat in Hom glo, nooit deur Hom verlaat sal word nie. Daar het nou 'n verandering van aksent gekom, en die bedeling van vroeër het die ou bedeling, die ou verbond, die ou testament geword. Die verskuiwing word dus nie negatief deur Paulus bewerk nie maar positief deur Jesus (vgl. Miller, 1986:10). Daarom word die Evangelies nie deur klaging gekenmerk nie en bevat die gebed wat Jesus sy gelowiges geleer het, nie klaging nie. Hierdie gebed begin teosentries en eindig met lof aan God. Die aksent is nou verplaas van die vraag oor die oorsaak van ons lyding na ' $n$ vraag oor die doel van ons lyding: om as verloste tot diens van God en ons naaste te leef en daarin God te verheerlik.

\section{- Die plek van sang in verband met lyding}

'n Voor die hand liggende plek vir die bediening aan die lydendes en veral vir die 'selfbediening' van die lydendes is die omgang met die Skrif. Wat die Ou Testament betref, raak dit veral die boek Psalms. Selfbediening kan gedoen word deur die Psalms persoonlik te lees, maar ook om dit as huisgesin te sing. ' $n$ Verdere geleentheid is dié in die openbare erediens. Hier is die stelling van Fuchs (1982:37) ter sake: die leed van die enkeling loop altyd weer gevaar om privaat te word en hom in vertwyfeling, vereensaming en verlatenheid te dompel. Die indiwiduele klaaglied wys daarteenoor die weg uit hierdie gevaar deurdat dit die bidder help om sy nood nie slegs aan God te stel nie, maar ook aan die gemeente. Gerstenberger (1992:21; vgl. ook Miller, 1986:7) wys op die toenemende isolasie van die enkeling in die moderne tegnologiese samelewing. 
Uit die voorafgaande blyk weer die besonder belangrike plek van die gemeentesang en verder die keuse van die psalms deur die liturg. 'n Leemte is dat slegs 'n beperkte getal psalms gewoonlik in eredienste gesing word terwyl ander kwalik of nooit aan die orde kom nie. Hiermee word die saak van die aard van die gemeentesang aangesny. Indien die gemeentesang nie ' $n$ geleentheid is waar mense werklik op begeesterde wyse uiting gee aan hulle innerlike gemoedstemming nie, word ' $n$ uiters belangrike middel om die lydendes in hulle lyding by te staan, onbenut gelaat. Gemeentesang is 'n bedieningsmiddel waarin God in werklikheid self die subjek is, synde die inspireerder van die Psalms.

\subsection{Die gemeenskap van die gelowiges}

Lydensbediening moet nie opgaan in klaging oor die lyding nie, maar moet ook bystand deur die gemeenskap van die gelowiges insluit en selfs afweer van lyding waar moontlik. Daar is groepe lydendes wat in die Ou Testament dikwels by name genoem word - lydendes soos siekes, armes, verdruktes, weduwees, weeskinders en vreemdelinge. Hierdie groepe verdien dus besondere aandag. Ook die individuele en kollektiewe oorsake moet betrek word, insluitende veroorsakende samelewingsinstellings, -patrone en -strukture. Die bediening moet nie net water opdroog nie, maar moet ook minstens die lekkende kraan uitwys. Die bestaan van skreiende armoede tas die eer van God die Skepper en Onderhouer van alle dinge aan (vgl. Duquoc, 1992; Gerstenberger, 1992).

Gelowiges is dus verplig om breër as hulle eie kring belang te stel en mense in nood te help. Die formulier vir die bevestiging van diakens in die Gereformeerde Kerke sê dan ook dat daar aan alle mense hulp betoon moet word, maar in sonderheid aan die huisgenote van die geloof. In watter mate hierdie sake binne die opdrag van die diakonale versorging val, kan nie hier bespreek word nie. Die feit is egter dat die diens van die diaken ' $n$ beskeie en passiewe plek in die Gereformeerde Kerke inneem en daarby hoofsaaklik deur onervare jongmense beman word. Veral in ' $n$ land waar skreiende armoede heers, vra dit emstige aandag. Verder roep kanale vir hulpbetoon aan lydendes soos blindes, gebreklikes, verstandelik gestremdes en ander om effektief beman te word. Ons samelewingsopset vra 'n deegliker orientering in verband met die behoeftes, die vasstelling daarvan en die hulpbetoning daarin.

\section{Samevatting}

Volgens die Ou Testament moet die lydende persoon God erken as vrymagtige Regeerder wat ten volle in beheer van alle dinge en gebeurtenisse is, ook van die oorsake van die mens se lyding. Hoewel sonde hierin 'n belangrike rol speel, is daar nie altyd 'n direkte verband tussen iemand se lyding en een of ander spesifieke sonde nie. Die gelowige se lewe moet trouens gedra word deur dankbaarheid vir God se grondelose genade en hy moet daarom uit 'n gesindheid van 
diensbaarheid leef. Die lydende moet oor sy lyding dus nie net oorsaak-georiënteer wees nie, maar veral doel-georiënteer. Selfs in die moeilikste omstandighede moet hy uit vertroue in God leef. So 'n lewenshouding hou in dat hy God se misterievolle optrede in die gevalle en sondige wêreld en mensdom waarvan hy deel is, erken en hom in sy lyding onvoorwaardelik aan die Goddelike bestier toevertrou. God is op pad met die mens na 'n sinvolle bestemming.

In sy verhouding met sy naaste moet die lydende nie vashaak by vyande nie, maar eerder die moeilike, selfverloënende maar bevrydende weg volg om lyding wat ander hom aandoen, vrywillig te aanvaar en hulle tot bekering te help lei. Lydensbediening moet ' $n$ atmosfeer van selfverloèning en versoening in die samelewing help skep.

Die lydende moet steeds gedra word deur ' $n$ verbondsbewussyn en daarom van sy deelwees van ' $n$ verbondsgemneenskap wat hom bystaan. Hy moet bokant homself en sy lyding en vertwyfeling uitstyg en sy blik op God se verbondstrou rig in selfaansporing tot vertroue op God. Verder moet hy so oorgegee wees aan God en sy diens dat hy onwrikbaar vashou aan die hoop op die dag dat hy God vir die uitkoms sal kan loof en prys.

Gelowiges moet nie net 'n oop oog, hart en hand vir die lydendes in eie midde hê nie, maar vir alle mense; ook vir die lyding wat deur die gevallenheid van die aarde veroorsaak word en vir die verpligting om as rentmeesters op te tree en besoedeling ensovoorts teen te werk. So moet gelowiges wys dat hulle in diens is van Hom wat oor die hele aarde regeer en wie se bewoënheid oor alle mense strek.

\section{Bibliografie}

BALLENTINE, SE. 1989. Prayers for Justice in the Old Testament : Theodicy and Theology (atholic Biblical Quarterly, 51(4): 597-616

BEYERLIN, W 1967. Die tôda der Heilsvergegenwărtigung in den Klageliedern des Einzelnen Zeitschrift für die alltestamemliche Wissenschaft, 79:208-224

BROYLES, C C 1989 The Conflict of Faith and Experience in the Psalms: a Form-Critical and Theological Study Sheffield : JSOT Press (Journal for the Study of the Old Testament Supplement Series.)

BRUEGGEMANN, W. 1992 Old Testament Theology: Essays on Structure, Theme, and Text Minneapolis : Fortress

DUQUOC, C 1992. 'Who is God?' Becomes 'Where is God?' The Shift in a Question (In Duquoc, C. \& Floristan, C. eds Where is God? A Cry of Human Distress London SCM Concilium 1992/4 p 1-10)

EISSFELDT, O 1945/48 "Mein Gott" im Alten Testament Zeitschrift fiur die alltestamenliche Wissenschaft, 61:3-16

FLOOR, L. 1981. Die evangelie van die koninkryk Pretoria : NG Kerkboekhandel

FUCHS, O 1982 Die Klage als Gebet eine theologische Besinnung am Beispiel des Psalms 22 Munchen: Kosel 
GERSTENBERGER, E.S. 1980. Der bittende Mensch : Bittritual und Klagelied des Einzelnen im Alten Testament. Neukirchen : Neukirchener Verlag.

GERSTENBERGER, E.S. 1992. 'Where is God?' The Cry of the Psalmists (In Duquoc, C. \& Floristan, C. eds. Where is God? A Cry of Human Distress. London : SCM. Concilium 1992/4. p. 11-22.)

HELBERG, J.L. 1993. Die verbondsverhouding as basis vir klag en lof in Psalm 42 en 43 . In die Skriflig, 27(1):109-122

KEEL, O. 1969. Feinde und Gottesleugner. Stuttgart : Katholisches Bibelwerk. (Stuttgarter Biblische Monographien.)

KREUZER, S. 1983. Der lebendige Gott: Bedeutung, Herkunft und Entwicklung einer alttestamentlichen Gottesbezeignung Stuttgart : Kohlhammer. (Beitrage zur Wissenschaft vom Alten und Neuen Testament.)

KROEZE, J.H. 1961. Het boek Job. Kampen: Kok. (Commentaar op het Oude Testament.)

LAMPARTER, H 1961. Das Buch der Psalmen II Stuttgart: Calwer Verlag (Die Botschaft des Alten Testaments.)

LIMBECK, M 1977. Die Klage - eine verschwundene Gebetsgattung. Theologische Quartalschrift, 157:3-16

MILLER, P.D. 1986. Interpreting the Psalms Philadelphia : Fortress

OOSTERHOFF, B J. 1971. De afwezigheid Gods in het Oude Testament. Kampen : Kok

PERLITT, L. 1971. Die Verborgenheit Gottes (In Wolff, HW. red. Probleme biblischer Theologie. München : Kaiser. p. 367-382.)

PREUSS, H.D. I992. Theologie des Alten Testaments. II Stuttgart : Kohlhammer

REVENTLOW, H.G. 1986. Gebet im Alten Testament. Stuttgart : Kohlhammer.

RIDDERBOS, J. 1958. De Psalmen. II. Kampen : Kok. (Commentaar op het Oude Testament.)

RIDDERBOS, N.H 1970. De plaats van het loven en van het bidden in het Oude Testament: enkele beschouwingen over en naar aanleiding van Psalm 50:14,15 Kampen : Kok

RINGGREN, H. 1973 'lohim (In THWAT. I Stuttgart: Kohthammer. p 285-305)

SAKENFELD, K D. 1978. The Meaning of hesed in the Hebrew Bible: A New Inquiry. Missoula, Montana : Scholars Press (Harvard Semitic Museum Harvard Semitic Monographs )

SCHALLER, H. 1990. Asking and Thanking - a Meaningful Unity. Concilium, 3:1-6

SCHMIDT, W.H. 1971. 'lohim Gott (In THAT I Munchen : Kaiser Verlag. p 153-167.)

VON RAD, G. 1962 Old Testäment Theology. I. Edinburgh Oliver \& Boyd.

VRIEZEN, TH.C. 1966. Hoofdlijnen der theologie van het Oude Testament. Wageningen Veenman

WESTERMANN, C 1977 Lob und Klage in den Psalmen Gottingen : Vandenhoeck \& Ruprecht

WESTERMANN, C. 1990 Die Klagelieder Neukirchen : Neukirchener.

WRIGHT, C.J.H 1983. Living as the People of God: The Relevance Old Testament Ethics Leicester : Intervarsity Press 